\title{
EL REALISMO GROTESCO COMO RECURSO DE TRANSGRESIÓN Y SUBVERSIÓN EN LOS CUENTOS DE JORGE KATTÁN ZABLAH
}

\author{
Rima de Vallbona
}

\begin{abstract}
RESUMEN
Este ensayo revisa las diversas instancias carnavalescas que se observan en los cuentos del salvadoreño Jorge Kattán Zablah, al aplicar el realismo grotesco según lo interpreta Bahktin, como sigue: 1 . Cosmovisión jocosa; 2. Exageración que subraya una visión del mundo al revés; 3. Lenguaje y libertad propios del carnaval; 4. crítica irónico-satírica (que nunca llega a ser sátira menipea) de algunas realidades socio-políticas, económicas y religiosas de El Salvador, las cuales se observan en el resto de nuestro continente; 5. Intertextualidad carnavalesca como medio de transgresión y subversión contra esas realidades; y 6 . escatología y degradación con poderes regeneradores.

El corpus utilizado abarca los cuentos publicados en tres libros del autor y otros en diversas revistas literarias. Se aplica esta metodología para efectuar una lectura de esos cuentos a niveles profundos, y probar que la socarronería y el humor del autor no son medios frívolos de tratar los temas de la América Latina, sino de atacar los diversos problemas socio-político-económicos y religiosos de El Salvador, divirtiendo a los lectores.

Palabras clave: Realismo grotesco, carnavalesco (adj.), cosmovisión: intertextualidad, transgresión, subversión, degradación.
\end{abstract}

\begin{abstract}
By applying the grotesque realism, according to Mikhail Bakhtin's method, this essay reviews several carnivalesque instances observed in Jorge Kattán Zablah's short stories, as follows: 1. the comical cosmovision; 2. the exaggeration that underlines a topsy-turvy vision of the world; 3. carnivalesque language and freedom; 4. ironic-satirical critique (that never becomes a Menippus satire) of socio-political, economic and religious instances observed in Salvadoran realities, which are found in the rest of the continent; 5. carnivalesque intertextuality as a means to transgress and subvert those realities; 6 . scatology and degradation with regenerative powers.

The corpus of this essay covers Kattán Zablah's first three books and some stories published in various literary magazines. This methodology has the specific purpose of proving that the humor and irony used by the author in his texts are not a frivolous way to approach the subjects related to Latin America, but to attack El Salvador's various socio-political, economic, and religious problems by amusing the readers.
\end{abstract}

Key words: Grotesque realism, carnivalesque, cosmovision: intertextuality, transgression, subversion, degradation.

Rima de Vallbona. Catedrática Emérita, University of St. Thomas.

Correo electrónico: RVALLBONA@aol.com

Recepción: 8-5-04

Aceptación: 10-5-04 


\begin{abstract}
La risa carnavalesca [...] construye su propio mundo en oposición al mundo oficial, su propia iglesia, versus la iglesia oficial, su propio estado, versus el estado oficial. [...] Junto con la universalidad de la risa medieval, hay que recalcar otra notable peculiaridad: su indisoluble y esencial relación con la libertad. Es de observar que ésta es una risa no oficial; sin embargo, está legalizada.
\end{abstract}

Mikhail Bakhtin

\section{El realismo grotesco en los cuentos de Kattán Zablah}

La socarronería y el humor, cargados a veces de ironía en los cuentos de Jorge Kattán Zablah, representan una amena pero nada frívola forma de tratar los problemas humanos y socio-religiosos, amén de la ignorancia y la superstición en El Salvador y, por extensión, en los pueblos hispanoamericanos.

Tal manera de expresar el dolor y la protesta contra nuestros males colectivos en son de burla me lleva a plantear el aserto de que a lo largo de la narrativa de este escritor salvadoreño impera el espíritu carnavalesco. Se expresa éste por medio del realismo grotesco, tal como lo interpreta Mikhael Bakhtin (1984), cuando analiza el humor de Rabelais ${ }^{1}$.

Según Bakhtin, la risa carnavalesca, propia de la Edad Media y del Renacimiento, es una válvula de escape para las pasiones del vulgo. Por tanto, tiene a la vez un carácter renovador, regenerador, transgresivo y subversivo: el carnaval es la verdadera fiesta del tiempo cíclico, el cambio y la renovación (10). Además, encarna un rechazo a todo lo inmortal y lo completo y, por lo mismo, también un rechazo al gobierno, a la autoridad, a la tradición, a la iglesia oficial y a las costumbres, con el fin de construir su propio mundo (88).

La visión cósmica carnavalesca integra lo social y lo corporal como un todo indivisible. De ahí que el realismo grotesco no haga diferencia entre el arriba y el abajo, entre lo espiritual y lo corpóreo. La tierra devora, traga, se asocia a la tumba, pero también se asocia a las entrañas maternas y apunta al nacimiento o al renacimiento; las imágenes físicas de este realismo se relacionan con los temas de la fertilidad, el crecimiento y la abundancia (21).

Además de Rabelais, otros autores que han utilizado el lenguaje carnavalesco en el mundo hispánico son el Arcipreste de Hita, Cervantes, Quevedo, Valle-Inclán, Cela y muchos grandes humoristas cuyas obras están constituidas por aspectos asociados a ese espíritu y, por ende, tienen trazos del realismo grotesco.

En los textos de Kattán se pueden señalar, entre otros, los siguientes recursos del realismo grotesco: 1. la visión de Cojontepeque, la aldea salvadoreña que abarca la totalidad cósmica del mundo. 2. La exageración o proceso mitificador hiperbólico que subraya la visión del mundo al revés. 3. El lenguaje que también se regenera y se libera de lo convencional y establecido por la norma lingüística. 4. El acercamiento festivo a las paupérrimas y deficientes realidades socio-políticas y religiosas. 5. La intertextualidad para ridiculizar costumbres, 
ideologías y el lenguaje del sistema vigente. 6. Escatología y degradación, las cuales tienen poderes regeneradores en el mundo carnavalesco.

\subsection{Cosmovisión jocosa en los cuentos de Kattán Zablah}

Bakhtin interpreta la risa festiva de Rabelais y de otros escritores no como una reacción individual a un suceso aislado, sino como la risa del pueblo, dirigida a todo y a todos, incluyendo a los participantes del carnaval; esa risotada expresa el punto de vista y abarca la totalidad cósmica del mundo entero. Se trata de una risa ambivalente porque "es festiva, triunfante, y al mismo tiempo es burlesca y hace mofa de todo. Asevera y niega, entierra y revive": en el realismo grotesco, la pura negación es completamente ajena a la cultura popular (11-2).

En general, los cuentos de Kattán siguen la norma de los fabliaux medievales adaptados a la época contemporánea y al referente de Latinoamérica, cuyos pueblos de cierta manera continúan padeciendo de feudalismo. Son cuentos con unidad propia, pero entrelazados por los personajes, por el medio ambiente, por el autor implícito unas veces; otras, por el narrador, y sobre todo, por su ubicación en Cojontepeque.

Además, la burla festiva de esos textos va dirigida a todo y a todos; en ella participa el autor mismo disfrazado, en Estampas pueblerinas (1981), como Yirish El-Kattán, autor de "un cuento escrito en árabe", el cual contiene grandes verdades que obsesionan a don Alejo hasta tal punto que lo llevan a la locura (95). Como narrador protagonista y testigo, Yirish El Kattán reaparece en "El cuento oriental de don Abdalah" (95-101) y se presenta de nuevo en "El cuento occidental de don Alejo" (105-11).

El autor sigue disfrazándose en Acuarelas socarronas (1983) como el Mago Kattanás, “originario de los más remotos confines del Indostán”, quien trabó con Ña Tomasa Barillas una amistad "profunda y puntiaguda" (37-8). También como "un tal Nattak que trae acertados consejos para casos desesperados", en Por el carnaval de la vida² (1998: 38).

En Estampas, el autor se asoma como narrador protagonista y a veces como testigo bajo el disfraz de don Alejo, quien evoca recuerdos de su niñez desde el punto de vista infantil ${ }^{3}$. Continúa en Acuarelas como don Alejo, quien en "La extravagante sabiduría del cronista" (60-5) descubre y narra que los conocimientos de don Macario Cárcamo proceden únicamente de unos viejos "periódicos amarillentos" (62). Don Alejo se vuelve a encontrar en "La partida de don Abdalah", también de Acuarelas (87-94). Por último, reaparece en Por el carnaval de la vida en "Soñar no cuesta nada" y en "De cómo don Macario descubrió al Dios verdadero" (Carnaval: 49-55 y 89-92).

De las apariciones y desapariciones del autor disfrazado, la más curiosa se halla en el "Epílogo" de Estampas, firmado por Ricardo Jesurum, seudónimo del escritor Ricardo Lindo. Conociendo el uso variado de disfraces que utiliza Kattán, el autor de este epílogo se disfraza también con el atuendo de su seudónimo y le sigue el juego. Tal epílogo tiene una relación intertextual con el prólogo de Don Quijote y el que le hizo Unamuno a Niebla: hay en este texto un desdoblamiento, algo así como un juego de espejos, en el que se presenta el autor como "el turco [don Jorge] Kattán”, quien llegó a la casa del judío don Ricardo Jesurum, montado "en su alfombra persa, [la cual] entró por la ventana y se fue a parar frente al escritorio de don Ricardo". Éste recuerda que la familia de don Jorge Kattán "no provenía de Turquía sino de alguno de aquellos frondosos árboles genealógicos que florecen en Líbano o Argelia”. 
Ahí Kattán se pone a invocar a los "narradores de antigua prosapia" de su raza, como "la benemérita princesa Sherezada, el poeta Abou Nowas, el epónimo Cide Hamete Benengeli y tantos otros...”; los invoca para explicar que él ha decidido sumar su "nombre a la gloriosa lista e inmortalizar al mismo tiempo" a su pueblo y pedirle a don Ricardo que le haga un epílogo. Indignado al leer las calumnias que el novato autor ha levantado en sus textos a amigos suyos, don Ricardo se iba a negar a su pedido, pero por temor a que "el maldito vástago de Cide Hamete" le endilgue una de sus "diabólicas historias", no tuvo otro remedio que pergeñar el epílogo de Estampas pueblerinas (115-6).

En suma, es bien sabido que estas formas solapadas de disfrazarse el autor, intervenir y participar en el mundo de Cojontepeque son un hábil truco que utilizaron otros reconocidos autores.

En la obra de Kattán, no sólo el autor — quien cumple una función fática— entra y sale llevando diferentes disfraces de un libro a los que siguen, de un cuento a otro; también los personajes aparecen, desaparecen y reaparecen de libro en libro y de cuento en cuento. Así, el lector que toma en sus manos un nuevo texto de este escritor está familiarizado de antemano con los habitantes del pueblo. Ya en "La muerte de la barbera", la mayoría de estos protagonistas son introducidos así:

\begin{abstract}
Poco a poco los aldeanos se fueron presentando en casa de don Repilado. El primero en llegar fue el excura excomulgado don Serapio Topete; luego entraron los demás en el siguiente orden: el venerable brujo don Indalecio Barrientos, el connotado tesorero municipal don Lactancio Clavijo, el descreído maestro don Armando Contreras, el sapientísimo alcalde municipal don Everardo Salazar, el piadoso cantinero don Saturnino Aguado, el mezquino carnicero don Jacinto Corpiño, el salomónico juez de paz don Restituto Paniagua, el archicelebrado cronista oficial don Macario Cárcamo, la muy consultada adivina Ña Tomasa Barillas y el temible cura párroco de planta don Agustín Garfio. Detrás de ellos penetró la chusma pueblerina (1983: 16).
\end{abstract}

A esta lista hay que agregar las Hijas de María y la Flaca Esperanza, dueña y señora del burdel ${ }^{4}$. Don Elpidio Recabado no asiste al entierro, pero su presencia en las páginas de Kattán se destaca en "La etílica canonización de don Elpidio" como el "borracho por obligación" (1998: 46).

En fin, el lector se topa con esos personajes una y otra vez, como ocurre en las fiestas pueblerinas de la plaza. Juntos, cada uno de ellos constituye la totalidad del mundo que levanta barullo en la plaza y hasta en la cantina "El Patriota", donde el Consejo Municipal de Cojontepeque celebra los miércoles sus asambleas.

Entre los cuentos de Kattán, el de "La muerte de la Barbera" por sí solo se prestaría como modelo de las características propias del realismo grotesco. Eso porque además de contener todos y cada uno de los elementos arriba enumerados, trata de un velorio y un entierro que en sí son verdaderas juergas carnavalescas: los visitantes comenzaron a beber aguardiente con mesura, pero a medida que pasaba el tiempo, bebían sin comedimiento hasta el punto de ser calificados por el narrador con el epíteto de "báquicos juergueros". Así, "gradualmente el velorio fue degenerando en una macabra orgía" (18). Cuando llega la hora del entierro, "entre bombos y platillos, partió el cortejo por las estrechas calles empedradas". De camino al cementerio cae un torrencial aguacero y como todos vestían y no querían estropear "sus mejores galas", "se produjo la desbandada general de la veleidosa turba"; "toda aquella tropa de comediantes y de perdularios se había escabullido en irreverente estampida, maldiciendo al cielo por haberles aguado la fiesta" (20).

En esta sucesión de cuentos con unidad propia, pero entrelazados, como se dijo antes, por los personajes, por el medio ambiente y por la ubicación en Cojontepeque, se perfila un 
debilísimo hilo novelesco — otro punto de contacto con los fabliaux medievales- en el cual el verdadero protagonista es colectivo como en todo producto literario populista: Cojontepeque. Campeny-Queralt (1996) explica que este pueblo "no es mero telón de fondo, sino personaje protagonista, entre tantos personajes. Cojontepeque es, a la vez, tapiz y urdimbre, retablo y santos, escenario y acción". En realidad es el ombligo del mundo, el "paraíso en la tierra" (Kattán Zablah 1983: 46) visto al revés. Mirar el mundo al revés es otro recurso del realismo grotesco propio del carnaval como fiesta liberadora de normas impuestas por la tradición, o por la autoridad, o por la costumbre.

En Estampas, el narrador hace referencia una y otra vez sólo al "pueblo"; es el juez don Restituto Paniagua quien lo menciona por primera y única vez en ese primer libro de Kattán con el nombre de Cojontepeque en el cuento "El juez se tira otro" (66). Esto deja ver cómo el autor está aún en proceso de definir el humorístico mundo en el que se han de mover sus criaturas. El toponímico de marras y los personajes quedan definidos a partir de Acuarelas, el segundo libro de cuentos.

Con la agudeza que lo caracterizó siempre, Hugo Lindo explicó muy discretamente que Cojontepeque es "un pueblo en que se mezclan los nombres de dos localidades salvadoreñas, Cojutepeque y Quezaltepeque, con otro ingrediente: la picaresca de Kattán, acaso inspirada por su brujo o demonio personal, Kattanás”. (Kattán Zablah 1983: ver solapas del libro).

A la luz de ese aserto y del principio degradador con carácter reproductivo carnavalesco, la etimología jocosa toponímica de Cojontepeque cobra una dimensión cósmica medular para interpretar la visión del mundo del autor. El término se compone de dos sintagmas: "cojón", del latín vulgar coleo, que dio en italiano coglione, el cual significa igualmente "testículo" (y, por ende, apunta al órgano reproductor), como "tonto" y "majadero"; y del sintagma nahuatl "tepetl", que equivale a "cerro" y "montaña". Así, se funden en el nombre signos positivos y negativos: el poder reproductor del órgano masculino, la estulticia del pueblo y el carácter sagrado que se le ha venido otorgando desde tiempo inmemorial a la montaña: según Eliade, la cima de la montaña cósmica no sólo es el punto más alto del globo, sino también es "el ombligo de la tierra, el punto donde tuvo comienzo la creación" (Cirlot 1982: 308).

\subsection{La exageración que subraya la visión del mundo al revés}

Otra característica del realismo grotesco está constituida por la exageración o hipérbole que se manifiesta de diversas maneras, siempre subrayando la visión del mundo al revés. En general, se puede apreciar en las referencias a Cojontepeque y en las descripciones caricaturescas de personajes y de circunstancias. El sentido hiperbólico lo dan, en especial, los adjetivos y los adverbios con la enumeración acumulativa, el superlativo absoluto y algunas comparaciones que a menudo se vuelven irreverentes y hasta irónicas; otras contrastan con ese mundo aldeano por su carga de cultura. Se prestan a servir de ejemplo en Estampas "las relaciones yegüinas del indio Policarpo" que iban bien con la yegua Pancracia, pero ésta "empezó a ponerse cadavérica, arrocinantada" $(14)^{5}$.

En ese mundo visto al revés, Filocadio Bocanegra, el bizco al que el brujo Indalecio Barrientos ha dejado ciego con sus menjunjes, le dice al final: "Nu hay duda [...] que de bizco a ciego hay una gran diferiencia. ¡Gracias, don Inda! ¡Usté mi ha hecho subir un tantito más en la empinada escalera de nuestra sociedad" (Estampas: 29). 
En Acuarelas, Armando Contreras deseaba escribir una carta de amor "cuyas palabras se trasmutaran en verdaderos dardos engatusadores"; su carta la escribe recargada de estrambóticos vocablos absurdos que él saca del diccionario por considerarlos muy refinados. Esta carta que comienza con "Volátil y casquivana libélula" (54-5) representa un momento climático respecto de la exageración humorística en el discurso narrativo de estos cuentos y en la visión del mundo al revés.

En cuanto a las descripciones exageradas contenidas en Acuarelas, sirvan las siguientes: la esposa de Cornelio "poco a poco, debido a su inclinación a la pereza unida a una glotonería incontenible, se fue transformando en una gigantesca albóndiga humana" (82); el entierro de la Barbera se celebra "con un boato sólo comparable al del Santo Entierro"; y cuando durante el sepelio llovió, fue "como si de golpe y porrazo se hubieran abierto las compuertas del cielo de par en par" (20).

En los textos de Kattán abunda la festiva enumeración acumulativa al estilo de la que se citó antes en "La muerte de la Barbera" (Acuarelas: 16). En Carnaval, se puede apreciar, en especial en "De cómo el zopilote llegó a ser el redentor de las aves": allá, en la "Balestina" de su padre, Nabil Larach no añoraba a nadie ni a Cojontepeque con "sus jaurías de brujos, su enjambre de adivinadoras y estrelleros y sus incontables rebaños de beodos profesionales" (20). Obsérvese aquí cómo esos personajes son agrupados bajo nombres colectivos que se aplican a los animales ${ }^{6}$. Lo que él extrañaba eran los pájaros tropicales de esas latitudes.

El proceso mitificador hiperbólico que convierte a Cojontepeque en ombligo del mundo llega al clímax cuando Nabil lo divisa en lontananza:

\footnotetext{
El corazón le empezó a palpitar con acusada ansiedad. Visto así, desde las alturas, el pueblecito, con sus negruzcos tejados y su blanquecinas paredes, le parecía el teclado de un descomunal y alucinante piano hecho a la medida de Gargantúa. Y la torre de la vetusta iglesia, lo único que sobresalía, se alzaba ante su imaginación cual gigantesco metrómetro dispuesto a marcar la cadencia musical de un ciclónico concierto (23).
}

En Cojontepeque, Nabil se tiene que enfrentar con la "Minotáurica y ciclópea realidad de que no hay pájaros porque están en vías de extinción" debido a los pesticidas que se aplican a los algodonales (23). Este pasaje, además de estar escrito con una serie de términos hiperbólicos, entre burlas y bromas toca la delicada vena de la crítica socio-político-económica, la cual recorre los textos de Kattán.

Nabil se convierte en el bíblico Noé salvador, esta vez de las especies avícolas, al poner en práctica el plan ecológico de salvar los pájaros haciendo que los empollara el zopilote porque éste sobrevivía a los pesticidas y además abundaba. Así es como en "insólita ceremonia zopilotesca" del pueblo, se levanta una "formidable estatua zoomorfa" que convierte al zopilote en el "excelso pájaro nacional" (28).

Más que en los otros, en este cuento no sólo es obvio el marcado espíritu carnavalesco por estar construido a base de exageración, sino también por el carácter regenerador que tiene el zopilote como símbolo; emparentado con el buitre, participa con éste del sentido que Jung le atribuye: entre los egipcios, se le asigna al buitre el atributo de la maternidad, pues por nutrirse de cadáveres, tiene relación con la madre naturaleza y con la muerte (Cirlot 1982: 106). Respecto de las aves en general, es interesante la interpretación que ofrece Loeffler: "el pájaro, como el pez, era en su origen un símbolo fálico, pero dotado de poder ascendente (sublimación y espiritualización)". Este autor explica que la presencia de 
los pájaros colaboradores del hombre se ha extendido universalmente en mitos y cuentos como portadores de poderes celestes y creadores del mundo inferior (En Cirlot 1982: 352).

En su estudio estilístico de los cuentos de Kattán, Isolde J. Jordan escoge como ejemplo de la exageración que se da sobre todo a nivel léxico, la carta que Melitón Parada, el don Juan de Cojontepeque envía a la mujer que se propone conquistar y que reza así:

Volátil y casquivana libélula:

Si columbrar pudieras la atrición que hasta el occipucio me tonsura, socorrido me habrías luenga tempore ha y estarías hogaño ofrendándome edénicos colutorios en las mefíticas fístulas que con virulencia me consumen, tornándome otra vez salubérrimo y eucrático como antaño.

La carta sigue y termina con: "Recibe tres alados ósculos en tus impolutos befos. Tu hipocondríaco esclavo, Melitón Parada" (Acuarelas: 55-6).

Esta rebuscada carta es motivo de que Melitón pare en un manicomio al final del cuento. Jordan indica con gran acierto que el pecado de este don Juan pueblerino fue el de "haber intentado una suprema elegancia estilística mediante el uso de palabras amaneradas", vocablos empleados inadecuadamente y hasta "transferencias insultantes como 'befos', palabra que significa 'labios', pero que se aplica normalmente a los caballos” (Jordan 1998: 288-9) ${ }^{7}$.

\subsection{Lenguaje y libertad propios del carnaval}

Con el fin de dar el tono jocoso de sus textos, el autor aprovecha todos los recursos lingüísticos que le proporcionan tanto la pintoresca habla del labriego, como la retórica pueblerina del empleado administrativo. El lenguaje coloquial, junto con los nombres de los personajes — reflejo del ingenuo mundo rural de Hispanoamérica— son también modalidades del humor carnavalesco: contrastan con las normas lingüísticas de la ciudad; también con los nombres propios que el habitante de los centros urbanos selecciona cuidadosamente según ciertos convencionalismos estético-culturales; éstos lo llevan a rechazar como denigrantes e irrisorios el de Filocadio, Policarpo, Tiburcio, Lactancio, Repilado, Próculo, Venancio, Afrodisio, Petronila, Melitón, Elpidio, Serapio, Macario, Lamberto, Rufaldo y otros más con los que se presentan los personajes en los cuentos que motivan este ensayo.

El espíritu carnavalesco de estos textos radica en la capacidad innata del campesino, quien vive liberado del punto de vista que prevalece e impera como norma en el resto del mundo y que forma parte de la cultura oficial. Según Bakhtin,

esta liberación de "convencionalismos y verdades establecidas, de clichés, de todo lo rutinario y universalmente aceptado [brinda la oportunidad] de tener una nueva visión del mundo, comprender lo relativo que es todo lo que existe y entrar en un orden de cosas completamente nuevo" (1984: 34).

La manifestación del realismo grotesco en los textos de Kattán no para ahí. También el autor implícito se toma amplias libertades lingüísticas; entre ellas, Isolde J. Jordan (1998: 289) señaló las desproporciones entre el vocablo y la situación descrita, la abundancia de superlativos absolutos, antítesis, hipérboles y lenguaje coloquial con el que se entreveran las palabras eruditas.

En los textos de Kattán, los adjetivos y adverbios, que abundan, tienen la función de captar con un leve trazo, y con mucha exageración, las diversas situaciones humorísticas. Los 
adjetivos en especial son una marca distintiva del discurso narrativo del autor, tanto que en algunas ocasiones se vuelven neologismos semánticos de gran fuerza significativa e inusitada jocosidad. Se pueden aducir como ejemplos los que siguen: don Alejo se despide del "resucitado" Lázaro con un "tentacular abrazo"; Cipriano Escalante mantenía con Gertrudis Arrinconada un "noviazgo volcánico" (Estampas: 46, 58); "Ña Tomasa y el Mago Kattanás trabaron en esa ocasión una amistad tan profunda y puntiaguda que ni el calificativo de "inalámbrica' podría describirla” (Acuarelas: 37). Unos ejemplos de adjetivos en Carnaval se pueden apreciar cuando Nabil añora los pájaros de su terruño, lo que hace que el joven tenga "inquietudes pajarunas" y "tribulaciones pajariles" (22 y 27); don Indalecio, el brujo, da a su paciente una "abracadabrante receta" (29) ${ }^{8}$.

Estos adjetivos adquieren mayores proporciones humorísticas y a menudo hasta irónico-satíricas por el uso de los superlativos absolutos, los cuales representan "la inflexión morfológica que mejor se presta a la exageración", como lo señala Jordan en su ensayo (289). Ella aduce como algunos de los ejemplos, los siguientes, tomados de Acuarelas: "el prudentísimo alcalde" (47) y "la sapientísima sibila pueblerina" (35). Según Jordan, su presencia resalta de continuo el recurso de la exageración jocosa, pues no tienen fundamento en la realidad: "nunca llegamos a saber en qué consiste en realidad la infinita sabiduría del 'sapientísimo' alcalde"; además de que don Macario es erróneamente llamado "archicelebrado" cronista, pero "no posee ningún conocimiento histórico". Jordan concluye que "se trata de adjetivos de significado positivo que en el resto del relato permanecen sin fundamento o son abiertamente invalidados o negados por lo que sigue en el texto" (289), lo cual remite a la ironía.

Respecto de los adverbios humorísticos, se lee entre otros: el deshonrado Honorio "enfiló culebrónicamente" hacia el lupanar; a aquellos borrachos que nunca han trabajado los impulsa "una diabólica vocación que los precipita huracanadamente hacia los brazos de Satán"; don Agustín Garfio, el cura, cada vez que "se alimentaba etílicamente" se volvía muy parlanchín (Carnaval: 39, 46, 62, etc.).

Otro recurso de la exageración que aumenta la hilaridad son los símiles o comparaciones desproporcionados. Algunos poquísimos ejemplos tomados de Carnaval son: al comprobar el ultraje que le habían hecho a su esposa, Honorio pierde el apetito "al grado de quedar más descarnado que un ejote marchito" (29); la felicidad de Honorio y Concepción no sólo se había mantenido "firme cual granítica columna, sino que iba en franco y volcánico crescendo" (32). El desesperado Honorio, quien busca consejo, "reptando como una víbora cascabel, entró a duras penas en la madriguera del ex-cura" don Serapio Topete (38). Al referirse don Alejo a don Lamberto y su avaricia, dice que "es más apretado que un traje de torero..." (52).

En ese discurso narrativo, llama también la atención la presencia de la perífrasis o circunlocución. Ésta, generalmente de carácter erudito, al contrastar con las situaciones, abre espacios festivos en los textos. Ejemplos en Carnaval: "los vastos dominios de Lucifer" (59): el infierno; éste también es "la residencia incandescente" (74); "secuaces de Esculapio" (64): los médicos; "la divina lengua de Nerón” (66): el latín; "gran amigo de Baco" (77): el borracho.

Por su parte, y sin apartarnos del aserto de Jordan, Clark M. Zlotchew explica que en los relatos de Kattán el abismo entre "los sucesos narrados y la elegancia del lenguaje con que se narran dichos hechos" es lo que hace reír (1990: 150). Este crítico parte del principio de 
que en esos cuentos existe una "aparente simplicidad [... la cual] puede hacer creer que no hay estilo" porque no se nota; a esto él lo llama "mesura, continencia o templanza" (149). A partir de este aserto, procede a analizar las varias formas de la ironía de las que depende la comicidad en los cuentos de este autor salvadoreño, como

\footnotetext{
la circunlocución, el understatement [o subestimación], el oxímoron, el presagio, el eufemismo, la inocencia - real o fingida - del narrador, el recurso borgeano de decir lo central como si fuera parentético y, en general, del contraste entre la vileza y violencia de los hechos y la delicadeza y mesura del lenguaje con que se expresan tales acontecimientos (156),
}

además de muchos otros recursos que sería interminable abarcar aquí.

En apariencia, contrasta la opinión de mesura expresada por Zlotchew con la idea de la exageración que se ha venido analizando. Sin embargo, hay que reconocer que la riqueza del discurso narrativo de Kattán es en realidad un cajón de sastre por la variedad de sus recursos expresivos; éstos, al complementarse y contradecirse, constituyen el complejo entramado irónico-satírico de sus cuentos.

\subsection{El espíritu carnavalesco y la crítica político-social ${ }^{9}$}

El corpus que abarcará la presente sección de este ensayo comprende, además de algunos cuentos contenidos en los tres primeros libros de Kattán, otros publicados en diversas revistas. Estos cuentos, como los anteriores, son ligeros y escritos para divertir. No obstante, se dijo antes, lo trivial constituye sólo una apariencia, pues es obvio que requieren un nivel profundo de lectura y un conocimiento de la historia y de las realidades que motivan la burla para acercarse al sentido que entrañan: entre bromas y situaciones irrisorias en estos textos se incrementa la crítica irónico-satírica a las realidades salvadoreñas y, por extensión, a las del mundo hispánico. Según Bakhtin, este tipo de crítica puede equipararse a la alegre celebración de la primavera, del año nuevo, de las bodas, etc.; son celebraciones que llevan en sí un anhelo de cambio y renovación (99).

Es preciso tener en cuenta que el espíritu carnavalesco bakhtiniano no se relaciona sólo con la fiesta anterior a la cuaresma, sino también con una forma de protesta que entraña la crítica a la línea "oficial” de la política cultural de un país. De ahí que el contexto histórico-político se hace necesario en este tipo de análisis. Así, en la base de este estudio está el "ideologema", el cual asimila lo ideológico a lo semiótico, y por ende, las estructuras sociales a las estructuras textuales ${ }^{10}$. En el ideologema, cada significado es también necesariamente un significante (Siègle, Sociocriticism: 72). Aquí el mito desempeña un papel deformador del significado sin negar la historia. Enajena, al transformar la Historia en Naturaleza eterna; además, tiende a fabricar falsas generalizaciones, según Malcuzynski (1988: 23).

Tal lectura de los cuentos de Kattán pone al descubierto una visión artística del mundo en la que predomina la inconformidad con las diversas realidades que capta a lo largo de los textos. Estas realidades, atacadas con amena jocosidad, son, entre otras, la indigencia cultural de El Salvador y en general de nuestros pueblos; su poca capacidad administrativa; el egoísmo, la avaricia y engreimiento de muchos; la falsa piedad y equivocada vocación religiosa de otros; la hipocresía de algunos; la superstición como rémora al progreso de los pueblos hispánicos; su abulia y ominosa resignación; la estulticia que el autor llama "la frágil naturaleza humana", entre otras. 
Aunque continúan en la línea del realismo grotesco, es interesante observar que en los cuentos de este estudio se perciben unos ligeros cambios en relación con los anteriores. El más obvio es que desaparece el autor que en los tres primeros libros entraba y salía disfrazado de un cuento a otro, de un libro al siguiente.

En los últimos cuentos, el autor implícito es sustituido por "don Macario Cárcamo, el célebre cronista oficial de Cojontepeque y de las aldeas circunvecinas" (Carnaval: 41). Don Macario es el que ejerce la misma función de Patronio, el consejero del Conde Lucanor en el libro del Infante don Juan Manuel. Pero Patronio es un consejero serio, formal, circunspecto, parsimonioso, sabio y culto por excelencia. A diferencia de esta imagen seria del consejero castellano, ya sólo en el nombre, el Macario Cárcamo de los cuentos de Kattán, simbólicamente asoma el mito deformante y la parodia. Según Bakhtin, los nombres propios en los textos del realismo grotesco "tienden a alcanzar límites de elogio y abuso" (Bakhtin 1984: 461), lo cual ocurre también en algunos nombres de los protagonistas de Kattán.

En sentido serio y positivo y hasta laudatorio, "Macario", de origen griego, significa "bendito, referido al que tiene todo lo necesario y es feliz"; además, hace pensar en San Macario de Egipto o El Antiguo, quien vivió durante el siglo IV después de Cristo y escribió cincuenta Homilías y siete Opúsculos ascéticos. En contraste, don Macario saca sus conocimientos de unos cuantos periódicos viejos; además, se jacta de haber leído sólo un libro: Don Coyote de la Mancha; y al recordar su viaje por España, menciona en especial El Alambre de Granada, El Mosquito de Córdoba y la Jirafa de Sevilla (Acuarelas: 61).

Asimismo, el apellido Cárcamo se asocia con "carcamal". En Corominas aparece "cárcamo", que se emplea también en el doble sentido de "carroña y viejo achacoso", de donde se deriva el término moderno de "carcamal", que significa "vejestorio, persona vieja y achacosa". En América, según Corominas, se ha afianzado una variante, "carcamán", que en Perú alude a un "extranjero de poco viso, fullero, basto y tosco"; en Cuba, es una "persona de muchas pretensiones y poco mérito".

La crítica a la línea oficial de la política cultural del país es obvia en "La frágil naturaleza humana" (Kattán Zablah 1994), texto en el que se plantea una situación que apunta a la realidad histórico-política de El Salvador: en el marco narrativo, el narrador cuenta que después de doce años de

cruenta lucha, no quedaba ningún sobreviviente que pudiera jactarse de haber salido ileso de aquel devastador maremágnum. Había sido una contienda en la que cada uno de los ciudadanos tenía algo que lamentar; sea la muerte o las lesiones de algún pariente o amigo o, simplemente, daños de carácter material (194).

Al cabo de dos meses de haberse firmado los acuerdos de paz y pasada la euforia colectiva, comenta el narrador que el jolgorio de los comienzos fue "reemplazado por una sensación indefinida que empezaba a revestir la forma de un desgano [...] un verdadero estreñimiento anímico" (194). Esto lleva al alcalde a convocar al pueblo y preguntar qué les pasa. Con la consabida actitud abúlica de nuestras gentes, deciden que no vale la pena "quebrarse la cabeza" buscando una solución, cuando ahí está don Macario Cárcamo, quien lo puede hacer por ellos. Entra entonces "el octogenario cronista, perfumado y almibarado por la lisonja" y se pone a leer un relato que halló "en una vieja gaceta capitalina" para ayudarlos a salir de tan peligroso estado. 
En el ejemplo que don Macario les lee, don Arnulfo es un campesino que por mucho tiempo vive obsesionado en su empeño de tapar, en vana tarea "digna de Sísifo", una gotera que lo mortifica cada vez que llueve. Una y otra vez la tapa y una y otra vez vuelve a aparecer. Sin embargo, llega el día en que la gotera desaparece para siempre. Entonces, después de su euforia del principio, el campesino está aturdido como si le hubieran quitado una parte del cuerpo o algo muy suyo, y es que "sin que él mismo se hubiera percatado, su existencia [...] giraba en torno a la serie de mortificantes ruidos [de la gotera] y a las diversas maneras de eliminarlos, de desterrarlos permanentemente de su vida" (196). Dominado por una especie de perturbación mental, "se desinteresó no sólo por su aseo personal sino que, incluso, llegó a desatender sus cultivos" (196). Una tarde de copiosa lluvia, "como poseído del demonio" se puso a taladrar agujeros en las tejas de su vivienda. Entonces "los vecinos se quedaron con la inequívoca impresión de que don Arnulfo era ahora, de veras, un hombre feliz” (197).

Una lectura en dos niveles de este cuento nos lleva a establecer varias relaciones: lo social y filosófico nos remite al título del texto, "La frágil naturaleza humana" y a la negativa conclusión, expresada por el mismo narrador del cuento, de que "el hombre no es más que una contradicción ambulante, un ser engendrado por error o descuido de las deidades, una genuina aberración" (196).

También en el nivel socio-político, remite a la historia de El Salvador: después de las guerras de la independencia, durante el resto del siglo XIX, la historia registra largos períodos de turbulencia alternados con conflictos armados contra los países circunvecinos. Durante el siglo XX hay inestabilidad política debido a fraudes electorales. En especial, a partir de 1977, con la elección declarada fraudulenta del General Carlos Humberto Romero, la situación se deterioró a tal punto que se produjeron en las calles asesinatos efectuados tanto por los izquierdistas como por los de la derecha. La violencia continuó y se intensificó, de manera que entre 1979 y 1983, en sólo cuatro años, habían muerto 35000 civiles, y en los doce años de guerra civil, más de 75000 perdieron la vida. Guerrilleros de la izquierda causaron algunas de esas muertes, pero la mayoría se les atribuye a los escuadrones de la muerte de las derechas. No fue sino hasta 1992, bajo la jefatura de Cristiani, que un tratado de paz concluyó con la guerra civil de El Salvador ${ }^{11}$.

Dos minicuentos más recientes de este autor, "La infalibilidad de la sibila" (1996) y "De la magnanimidad de Dios, ¡líbranos, Luzbel!” (1995) ${ }^{12}$, relacionados con el mismo tema, dan la impresión de ser parte integrante del anterior. Además, con jocosidad ponen en evidencia las trágicas consecuencias de toda guerra.

En "La infalibilidad de la sibila", el señor presidente visita a Ña Tomasa Barillas, cuya fama "ha rebasado ya las estrechas fronteras del país" por la exactitud de sus predicciones. El alto dignatario le pide consejo porque piensa "invadir una nación vecina". Na Tomasa le responde: “'Si lo hace, su Excelencia, destruirá usted un gran país!”. Tal como lo predijo la sibila, el señor presidente "terminó destruyendo un gran país: el suyo propio" (3). Este relato no sólo pone en relieve la torpe soberbia de nuestros mandatarios, sino también satiriza la costumbre de algunos de ellos al consultar asuntos peliagudos de sus respectivos países con nigromantes, adivinos, brujos y echadores de cartas.

"De la magnanimidad de Dios, ¡líbranos, Luzbel!" es otra versión del tema de las consecuencias de la guerra y de la voluble y "frágil naturaleza humana": cansado el Todopoderoso de escuchar las plegarias no solo del pueblo de Cojontepeque, sino también de la nación entera, les concede sus peticiones: pone fin a la guerra y les otorga la paz. Con ésta, 
también les concede los ruegos suyos de que regresen al país sus "hermanos del alma que ya suman casi la mitad de la población total". Dios no ha acabado de satisfacer sus súplicas cuando el pueblo entero comienza a importunarlo con una nueva plegaria para que no permita "que regrese al país ni siquiera uno solo de [... los] hermanos expatriados" (15). La nueva súplica la justificaban en el hecho de que los giros bancarios

\footnotetext{
que con religiosidad enviaban [los exiliados] a su querido terruño, se habían convertido, imperceptiblemente y sin proponérselo, en el sostén económico de la otra mitad de la ciudadanía que nunca logró o intentó abandonar el suelo patrio durante el prolongado período bélico (15) ${ }^{13}$
}

El narrador cincuentón remata el minicuento cuando comprende por fin "las sorprendentes, sapientísimas y admonitorias palabras” que su tía le reveló de niño: “iMuchacho, ten mucho cuidado con lo que le pidas al cielo, porque Dios es capaz de concedértelo!” (15).

Al principio de este ensayo quedó mencionada la crítica que subyace en "De cómo el zopilote llegó a ser el redentor de las aves", la cual tiene una intención ecológica: ataca la codicia de quienes, para proteger sus cosechas, utilizan poderosos pesticidas que causan "gran mortandad de pájaros, diezmando bandadas enteras y contaminando sus huevos". Además, al referirse a "los terrenos que antes se dedicaban al cultivo del histórico maíz y de la generosa caña de azúcar" y que lo ocupan los algodonales apunta al fallo económico de nuestros países que con fines lucrativos y por las múltiples demandas extranjeras del momento se dedican al monocultivo (Carnaval: 24).

En el cuento "Los mapaches", los pueblerinos, reunidos en la cantina "El Patriota", hablan de la necesidad de que se produzca una revolución para sacar del gobierno a aquellos que acostumbran "agarrar a manos llenas lo qu'es de los pobres" (Acuarelas: 24).

Otra sutil crítica irónico-satírica al gobierno va dirigida a los múltiples e innecesarios puestos y se puede apreciar en "La etílica canonización de don Elpidio"; éste "ostentaba el puesto de asistente del tercer secretario del subsecretario de la secretaría del juez de paz" (Carnaval: 35). Respecto de la deshonestidad y corrupción en los puestos públicos, don Macario Cárcamo cuenta que durante su "culebrónica carrera tribunalesca" don Elpidio

\footnotetext{
vio cómo los casos más espinudos y escandalosos se resolvían con una botella de aguardiente y cómo unos cuantos billetes de a peso le cambiaban hasta el modo de andar al más casto e incorruptible ciudadano. Vio, con sus ojos avizores, cómo con dádivas de por medio los hurtos no eran hurtos, las violaciones no eran violaciones y los homicidios no eran homicidios... (Carnaval: 44)
}

Don Elpi “todo lo calló para no poner en peligro su futura y anhelada jubilación” (44). Don Macario explica a los chiquillos: don Elpidio Recabado es "el primero en nuestro insigne pueblo en alcanzar, para orgullo de nuestro pabellón nacional, el maravilloso don de la jubilación" (42). Irónicamente, se le concedió solo en los documentos oficiales y, al no llegarle nunca su pensión, don Elpi se convierte en "borracho por obligación” (42).

En "El Compadre", la presencia del gringo Mr. John Mason, alias Compadre, quien introduce grandes mejoras sanitarias en el pueblo pone de manifiesto la abulia de "las autoridades edilicias", las cuales no se habían cuidado de la higiene ni de la salud de los habitantes de Cojontepeque (45-50). Sin embargo, el gringo no se salva de la crítica solapada de los lugareños. Uno de ellos, indignado, exclama: “¡Estos gringos hijos de la guayaba le han vuelto a bajar el precio al café!"’. Otros dicen que “con su dinero están corrompiendo el mundo entero”; 
y por supuesto, en Centroamérica no podían faltar las acusaciones contra la United Fruit Company, a la que ellos llaman Yunaited, pues es la que manda en el pueblo; además, nunca se hacen realidad las promesas de veinte años atrás de darles una nueva carretera que los una con la capital $(44,50)$.

En los cuentos de Kattán, los juicios críticos se extienden también a los ámbitos religiosos. En su interesante ensayo relacionado con la sátira anticlerical, Robert A. Parsons observa en dichos textos "una actitud aparentemente antirreligiosa [...] como una desconfianza hacia la autoridad de las instituciones eclesiásticas y una crítica jocosa e irreverente contra los representantes de la Iglesia" (1998: 269). Observa este crítico que "a pesar de que muchos sacerdotes son objeto de burlas de Kattán, el verdadero blanco de su sátira lo constituyen la hipocresía, la beatería y el boato ceremonial de la tradición religiosa" (271).

La opinión de Julio Ricci (en Kattán 1983: 10) acerca de estos cuentos capta muy bien la trascendencia crítica que entraña tal humorismo respecto de las realidades hispanoamericanas; por lo mismo, sirva de resumen y remate para esta sección:

\begin{abstract}
La socarronería y la vena humorística de Kattán son más que nada un artilugio moderado con el que busca poner en clave literaria una honda preocupación ante los problemas de una sociedad alimentada por la injusticia, la irracionalidad y la superstición [...] Nada aparece en sus textos frívolamente sugerido ni rebuscado como ocurre en muchos narradores actuales [...] Tras esa aparente sencillez se oculta la profundidad de un mundo de ideas muy incisivas y de una problemática muy sentida.
\end{abstract}

\title{
1.5. La intertextualidad carnavalesca como medio de transgresión y subversión
}

Don Macario, el cronista oficial de Cojontepeque, aconseja a los individuos del pueblo narrándoles cuentos o ejemplos que él extrae de las crónicas, de la gaceta y de la tradición oral, con lo cual pretende proporcionarles soluciones. Estos textos narrativos se definen como estructuras orientales, de las que provienen las del cuento dentro del cuento y el débil hilo novelesco, propio del Medioevo.

La variedad de documentos usados como ejemplos por don Macario remite a las relaciones intertextuales de la carnavalización, a las cuales en otro tiempo se les consideró como el estudio de las fuentes literarias. Recordar que el realismo grotesco sostiene que todo proceso intertextual es en realidad una parodia en la que semánticamente se establece una relación más compleja; esta implica la puesta en ridículo de costumbres, ideologías y lenguaje privativo del sistema vigente. En dicha relación, los textos son el uno para el otro mutuamente dependientes y generativos. Iris M. Zavala (1988: 59-60) explica que políticamente hablando, "la carnavalización literaria emerge como necesidad de una revolución cultural que incluye la re-educación de las diversas clases sociales".

Las relaciones intertextuales en los cuentos de Kattán generalmente subvierten lo gratuito del texto original y cristalizan en una burla irónico-satírica, a veces sólo esbozada, de las realidades socio-políticas y religiosas del continente. Por lo mismo, resulta muy difícil trazar una línea divisoria entre el segmento anterior del presente ensayo y éste de la intertextualidad.

En "La frágil naturaleza humana”, podría establecerse una relación intertextual con "La cuestionable eficacia de la paz", sátira menipea del uruguayo Julio Ricci, en la que, según el narrador, "La guerra en realidad era una cosa entretenida". Después de estudiar estadísticas, queda rematado el cuento de Ricci con la siguiente conclusión: “circuló un hálito de duda. No 
se sabía si la paz sería beneficiosa. O sea, si la guerra había madurado suficientemente a los hombres y a las mujeres. La paz era todavía un problema" (1987: 11, 18).

El ejemplo del campesino don Arnulfo-quien después de tapar la gotera que tanto lo mortificaba, la abre de nuevo al comprender que su existencia giraba alrededor de los ruidos de la gotera - incluido en "La frágil naturaleza humana" tiene también relación intertextual con dos cuentos del autor: "Los mapaches" y "El mal amigo" (Acuarelas: 21-32 y 81-85, respectivamente $)^{14}$. "Los mapaches" es un relato independiente, o sea, que no está utilizado como cuento dentro de otro cuento; sin embargo, entre risas y burlas capta con hondura cómo los seres humanos dependemos muchas veces de lo que más creemos detestar.

En "Los mapaches" se entrevera la censura a la corrupción política del país con la obsesión del campesino Venancio. Este vivía desesperado porque los "malditos mapaches le amargaban la vida" abriendo zanjas en el césped (24). Al cabo de innumerables tentativas de deshacerse de los intrusos, al fin logran él y su esposa eliminarlos. Entonces, después de unos cuantos días de júbilo, "una melancolía crónica se apoderó de" ambos ancianos, "pues aquella continua incertidumbre de que no vinieran los animales a cavar el surco era el único alimento quimérico con que ambos se habían nutrido durante años". No logrando llenar "aquel vacío", los dos envejecieron y acabaron muriendo en el jardín, muy cerca de la zanja que antes abrían los mapaches (30 y 31-2).

En "El mal amigo", además de la intertextualidad con otros cuentos de Kattán, se observa la intertextualidad bíblica con el tema de Caín y Abel. Sin embargo, por el desarrollo del relato más bien se le puede relacionar con el Abel Sánchez de Unamuno: Cornelio mantiene un viejo rencor contra Cirilo porque a éste todo le va muy bien y consigue cuanto quiere. Pese a estos celos, Cornelio pasa la vida fingiendo que le corresponde como amigo. Sus perversos rezos pidiendo al cielo que Cirilo muera, son escuchados, pero su inmensa dicha le dura poco: "con la muerte de su enemigo la vida parecía haber perdido todo su sentido para él”, por lo que acaba ahorcándose (85).

"Castillos en el aire" representa un nuevo acercamiento a la fábula de los sueños truncados de la lechera divulgada por La Fontaine. La intertextualidad de este tema se remonta a muy lejanos tiempos: una de las más antiguas versiones se conserva en El Patchatantra de la India con el título de "La olla rota"; aquí el texto trata de un brahmán que recibe una olla llena de arroz y en su entusiasmo, después de grandes sueños provenientes de la posible venta del arroz, rompe la olla. Pasa a Las mil y una noches con el título de "Historia del quinto hermano del barbero"; en este cuento, un barbero gasta toda su herencia en objetos de cristal, hace grandes planes con las ganancias que pretende conseguir, pero en su arrebato, da una patada y rompe toda la cristalería; en esta versión de esencia moral, se castiga el orgullo y la soberbia. En el siglo XIV, El Conde Lucanor recoge ese tema en el "Enxemplo VII", "De lo que contesció a una mujer quel dezían doña Truhana", donde el actante es ya una mujer; los sueños de ésta giran alrededor de una olla de miel que lleva al mercado. En el siglo XVIII, "La lechera y el cántaro de leche", de La Fontaine, recoge el asunto de nuevo y lo populariza. En este mismo siglo, Félix María Samaniego da otra versión en lengua española en su fábula II, "La lechera", cuya moraleja dice: "No anheles impaciente el bien futuro; mira que ni el presente está seguro".

El mejor ejemplo de la convergencia entre la intertextualidad y el escarnio dirigido contra las irregularidades socio-político-religiosas lo constituye el cuento "Castillos en el aire". Trata este de una humilde mujer, Florinda, quien va a la cantina a traer a su marido 
borracho, con la suerte de que a don Saturnino, el cantinero, se le cae un billete de la Lotería Nacional; disimuladamente, ella recoge "aquella posibilidad de llegar a ser rica" y comienza a imaginar "los jugosos beneficios que le podría acarrear el furtivo billete" (24). De divagación en divagación, concluye que las riquezas proceden del demonio y se dice a sí misma: " ¡Con razón [...] por allá, en los Estados Unidos, los ricos les dejaban sus fortunas a los gatos! ¡Claro, pa'no causarles tantas desgracias a sus seres queridos!". Entonces corre a la cantina a devolverle el billete a don Saturnino hablando para sí misma: “¡Que se joda don Saturnino! ¡Ese viejo de porquería sí se merece la mala suerte de ganarse el premio gordo!” (27).

Hay en este cuento salvadoreño una desviación radical de la moraleja tradicional hacia un remate cultural, el cual subraya el temor que la iglesia católica ha venido inculcando en los feligreses al hacer hincapié en que la posesión de riquezas engendra las asechanzas del demonio.

El remate del cuento no es la única desviación del tema original, ya que, siguiendo el espíritu carnavalesco que conjuga la intertextualidad con la subversión político-social, la intención de "Castillos en el aire" deja de ser moral para tornarse en una polivalente crítica a la realidad salvadoreña en particular, pero también hispanoamericana: en primer lugar, repite la consabida historia del representante del proletario y pequeño empresario hispánico, Jacinto, el marido dueño de una pequeña carnicería, quien se gasta el dinero en borracheras y francachelas y no satisface debidamente las básicas necesidades domésticas. A continuación, son los sueños de Florinda los que exponen el ataque a las siguientes situaciones socio-político-culturales y religiosas:

1. Contra los contratistas abusivos y sinvergüenzas que cobran excesivas sumas por el transporte de mercancías de los habitantes del pueblo (25).

2. Contra "todos los dirigentes políticos regionales y nacionales" para los que Florinda desea construir una escuela modelo donde aprenderían la "ilógica, entreverada y complicadísima arte de no robar y de no mandar a apalear y a violar a las mujeres y a las hijas de sus enemigos ideológicos" (25).

3. Contra los ministros de la iglesia, que se comportan como el "truculento del párroco, don Agustín Garfio, archiconocido por su apetito desmedido por los bienes materiales". Para salvar a Florinda del peligro que entrañan las riquezas, don Agustín le ofrecería la salvación de su alma "siempre y cuando buena parte de su fortuna la dedicara a decir misas y a comprar bulas e indulgencias" (26).

4. Contra los negocios sucios de los dirigentes políticos del pueblo, como

el alcalde municipal, don Everardo Salazar, hombre de afiladas uñas [... quien] la compelería, sin lugar a
duda, a invertir su dinero en negocios turbios, amenazándola, para el caso que rehusara, con decretar una
ordenanza que autorizaría la construcción de una ancha y pintoresca carretera que pasaría en medio de la
carnicería de su marido. Este alcalde, cuatrero de gran notoriedad, pero protegido por la ley debido a su
alto puesto y a su condición social, la forzaría, en resumidas cuentas, a asociarse con él en el asunto de
robar cabezas de ganado bovino, porcino y lanar y a proporcionarle suficiente dinero para comprar un
camión de dimensiones desmesuradas que serviría de matadero clandestino móvil, donde los animales mal
habidos serían destazados y cuya carne sería vendida, luego, en el establecimiento de Jacinto. Y no esti-
maba Florinda muy aventurado el afirmar que el desalmado don Everardo la obligaría, además, a que le
ayudara económicamente para poder hacerles mejoras a los dos burdeles de su propiedad. Y de todos estos
negocios inmorales - barruntó- seguramente que a ella apenas tocaría un miserable tres por ciento de las
utilidades (27).

Contra los maridos borrachines "a tiempo completo" que maltratan y abusan de sus mujeres dándoles "puntapiés y coscorrones" (27). 
Otra subversión al modelo tradicional, ya se dijo, lo constituye el remate del cuento, ya que en lugar de un accidente que destruye la fuente de los sueños, Florinda, la protagonista, renuncia voluntariamente a sus fantasías después de sopesar las tan nefastas posibles consecuencias que podrían traerle las riquezas en caso de ganar el premio mayor de la lotería.

También se puede establecer intertextualidad entre el cuento "El brujo" (Estampas: 23-9) y "La parábola del joven tuerto" de Francisco Rojas González (1955) 15: ambos tratan de dos jóvenes, uno bizco y el otro tuerto, desesperados porque ya no soportan más las burlas de los demás. Estos cuentos captan el mundo visto al revés del humor carnavalesco.

En "El brujo", Filocadio, dispuesto a suicidarse de tan desesperado que está por las constantes burlas de los otros, va a pedirle a don Indalencio, el brujo de Cojontepeque, una cura para su mal. La medicina que le aplica don Inda a los ojos lo deja totalmente ciego. Pasado un tiempo, Filocadio regresa a expresarle su profundo agradecimiento porque "de bizco a ciego hay una gran diferencia", ya que los que lo apedreaban ahora lo respetan y le dan "uno qui otro centavito"; además, reconoce que don Inda lo "ha hecho subir un tantito más en la empinada escalera de nuestra sociedad" (29).

El joven de "La parábola..." va a la feria de la Virgen de San Juan de los Lagos para rogarle que le haga el milagro de "templar la inclemencia del muchacherío" que le endilga toda clase de insultos porque es tuerto. Sin embargo, la varilla de uno de los cohetes prendido en las fiestas de la Virgen le cae en el ojo bueno y, para su desgracia, lo deja ciego. En su ignorancia, la madre celebra el trágico suceso como un milagro porque "todos quedarán chasqueados y no van a tener más remedio que buscarse otro tuerto de quien burlarse..." (59). Termina el cuento con la promesa de regresar al Santuario al año siguiente "para agradecer las mercedes a Nuestra Señora" (60).

En ambos cuentos, se aprecia la intertextualidad hasta en los temas: la crueldad humana ante los defectos del prójimo; la superstición y la fe ciega en los ciegos y en los milagros de la Virgen; la resignación llevada a extremos hasta de complacencia ante irremediables tragedias.

"La obsesión del tirano" (Carnaval: 75-80) tiene relación intertextual con el conocido cuento de "Barbazul". El de Kattán subvierte la intención de contar con el fin de entretener y se erige en escarnio de los gobernantes con tan insaciable "sed de poder" que los lleva a pasar "a cuchillo a todos los miembros de la oposición, reales e imaginarios" (75): como sus consejeros y allegados no logran sugerirle una forma "viable de lograr su quimérico propósito" de perpetuarse y alcanzar la inmortalidad, manda "degollar a cada uno de aquellos infelices servidores" (75). Entonces, hace llamar a don Macario, quien como de costumbre, le suelta uno de sus cuentos: el de un depravado que desea escapar de la inevitable muerte. El tirano queda tan satisfecho de lo que él deduce del cuento de don Macario, que lo premia. No solo eso: promete nombrarlo confidente y consejero suyo "con poderes plenipotenciarios" (80). Este remate del cuento resulta en una sátira a la estulticia de nuestros gobernantes que no solo se rodean de ministros ignorantes, sino que además tergiversan a su gusto los bien intencionados consejos que reciben.

En "La etílica canonización de don Elpidio", la paciente espera de la pensión que tanto merecía don Elpi remite a la trágica espera de la jubilación que recorre las páginas de $E l$ coronel no tiene quien le escriba, de García Márquez. En realidad, hay muchas otras instancias intertextuales en los cuentos de Kattán, las cuales generalmente se vuelven parodias político-sociales de los originales, pero sería el cuento de no acabar tratar de abarcarlas todas. 


\subsection{Escatología y degradación con poderes regeneradores}

Otro principio esencial del realismo grotesco es la degradación. Esta, como los principios antes vistos, tienen un aspecto destructivo y otro regenerador. Asociados a la degradación están los recursos escatológicos y la desacralización. En algunos de los cuentos de Kattán, se puede apreciar ese doble proceso destructivo y regenerador.

En "La etílica canonización de don Elpidio", la risa satírica va dirigida contra el sistema administrativo y contra la Iglesia: don Elpi, en espera de la pensión prometida por el gobierno, la cual nunca llega, se entrega a la borrachera "para olvidar que existe el Ministerio de Trabajo y cuanta institución pública se le parezca" (Carnaval: 46). Por eso, aclara don Macario, don Elpi "se dirige, a velocísimos pasos tortuguescos, hacia una segura canonización". Los chiquillos, sin comprender del todo el sentido de estas palabras, se lanzan entonces a arrancarle a don Elpi "a zarpazos jirones de sus pestilentes vestimentas hasta dejar al jubilado totalmente en cueros", con la esperanza de que tales "reliquias" los hagan merecedores de la "Gracia eterna" (47). Obsérvense los sintagmas religiosos que son utilizados aquí a la manera irreverente del carnaval.

Además, la absurda y burlesca interpretación "religiosa" del vicio etílico de don Elpi remite al ritual de la Edad Media llamado "miss de potatoribus" ("misa de los borrachos") durante el cual se seguían, en son de burla, los textos de la liturgia original. Asimismo, está la "Liturgia de los borrachos", que era una parodia de los evangelios. Aquí vale recordar que el alcohol, también llamado "agua de vida", es símbolo de "la conjunción de los contrarios, de la suma de dos elementos, activo uno y pasivo otro, fluidos y cambiantes, creadores y destructores" (Cirlot 1982: 61).

¿Y quiénes se apiadan de don Elpi? En ese mundo visto del revés, quienes se compadecen de él son las "recatadas y caritativas señoritas del lupanar de la Flaca Esperanza", ña Tomasa Barillas, la sapientísima adivina"; don Agustín Garfio, "el ex-cura excomulgado"; y el brujo don Indalecio Barrientes. En cambio, la abadesa de las Clarisas lo rechaza y acusa de que en sus borracheras "se desviste exhibiendo su menguada y agónica virilidad a los cuatro vientos". También lo rechaza el cura don Serapio Topete, porque "don Elpi ha convertido el sagrado atrio de la iglesia en su inodoro y vomitorio particular" (45).

Hay que tomar en cuenta que en el realismo grotesco "arriba" y "abajo", referido a lo corporal, "no se distinguen con claridad de lo cósmico: la parte de arriba es la cara o la cabeza y la de abajo son los órganos genitales, el vientre y las nalgas", según Bakhtin (1984: 21). Así, "la imagen del excremento, por ejemplo, no tuvo la connotación trivial y limitada a lo fisiológico" como hoy, ya que el excremento se concebía como parte vívida de la noción de naturaleza corporal estrechamente unida a la vida y a la tierra. Además, tiene un sentido liberador, pues representa "la muerte de lo caduco y el nacimiento de un nuevo mundo" (149 y 224).

Volviendo al acto desacralizador de don Elpi, vale la pena recordar que el carnaval encarna la liberación del dogmatismo religioso y eclesiástico. Es por esto que Bakhtin interpreta la orina, los excrementos y todo lo orgánico como "un principio de regeneración, fertilidad y renuevo" (150). Asimismo, las manifestaciones relativas al cuerpo en el realismo grotesco no se refieren a un ser biológico aislado ni individual, sino al colectivo ancestral de todo el pueblo (Bakhtin 1984: 19). Hay que tomar en cuenta que tradicionalmente "en leyendas y cuentos [y en la alquimia también] aparece la sorprendente relación entre las heces y el oro". 
En 1960, Norman O. Brown, en Erôs et Thanatos, define los excrementos como "vida muerta del cuerpo y símbolo de la felicidad de la vida corporal". Y finalmente Nietzche resumió el proceso efectuado por la alquimia en la siguiente frase: "Desde lo más bajo ha de alcanzar su ápice lo más alto". Por su parte, la palabra "orina" proviene del caldeo "ur", que significa "fuego de la naturaleza inferior" y, por tanto, no sólo es fuerza, sino también virtud (Cirlot 1982: 202 y 342).

Bajo el principio mítico-degradador con carácter reproductivo del espíritu carnavalesco, Cojontepeque se destaca como el ombligo del mundo, el "paraíso en la tierra" visto al revés y degradado: sus calles están plagadas de zopilotes, cerdos y borrachos, amén de las nubes de perniciosos mosquitos" (Acuarelas: 46). Para controlar este estado deplorable del pueblo, el gringo Mr. Mason construye pozos sépticos y basurales, pues "si pajarracos comecacas no ver caca, no visitar ciudad" (48). No obstante, don Afrodisio, el viejo poeta del pueblo, odia al gringo porque con sus medidas higiénicas le espantó "las musas que le inspiraban el lirismo de sus nauseabundos poemas" (50).

La degradación, propia también de los mitos y el principio esencial del realismo grotesco, consiste en "rebajar todo lo que es alto, espiritual, ideal, abstracto", para convertirlo en carne, ponerlo en contacto con la tierra que traga y da nacimiento a la vez. "Degradar es enterrar, sementar y matar simultáneamente, con el fin de producir algo mayor y mejor", explica Bakhtin (1984: 21). Esto hace evidente los dos aspectos, el destructivo y el regenerador, del humor carnavalesco.

Mientras a don Elpi se le canoniza carnavalescamente en el cuento anterior, en "El peligroso juego de la multiplicidad de pareceres" (1993), se humaniza al santo Papa en el cuento-dentro-del-cuento que se titula "El receptáculo ambulante". Para hacer que las autoridades municipales de Cojontepeque lleguen a un acuerdo acerca de la construcción de una represa, interviene don Macario leyéndoles un reportaje publicado en la gaceta, el cual versa así: el propietario de una modesta compañía de transporte explica en una entrevista cómo durante la reciente visita del Sumo Pontífice a esas tierras tuvo "la incalculable dicha de acarrear, con toda la pompa del caso, el inodoro portátil del Santo Padre". La Presidenta de la Cofradía de Santa Águeda no puede explicarse "la razón que tendría el Papa para descolgarse en nuestras latitudes acompañado de tal artefacto ambulante cuando aquí había excusados en todos los puntos cardinales" (316). Con el fin de satisfacer su curiosidad, hace un concurso. De los participantes recibe múltiples explicaciones, aparentemente históricas, pero llenas de humor. Uno de los concursantes con visos de teólogo dice:

\footnotetext{
Las secreciones y excreciones de los santos, y por consiguiente del Papa, que no lo es menos, han tenido la categoría de codiciadas reliquias inmemoriales y se les ha atribuido propiedades curativas y hasta milagrosas. Por ese motivo, incluso hoy en día, es posible adquirir en la Plaza de San Pedro, por moderadas sumas de dinero, filtros que contienen las lágrimas de la Virgen de Siracusa, la cera de los oídos de Santa Eulalia de Alejandría, el sudor de San Pantaleón El Bueno y las secreciones y excreciones de otros conocidos mártires del cristianismo. Para evitar, pues, recalcó el participante, que se comercie con bienes sagrados que son del monopolio exclusivo de la Santa Sede, el Papa, en sus giras, jamás se olvida de ir respaldado por su inseparable y fiel receptáculo (318)
}

La enumeración acumulativa y la referencia a las secreciones corporales con poderes curativos, contenidas en la cita anterior, son elementos degradantes milagrosos propios del realismo grotesco. En su estudio sobre la sátira anticlerical, Parsons comenta muy acertadamente que la comida y las excreciones se usan en la tradición satírica "para minar las 
altas pretensiones y para poner énfasis en los vínculos prosaicos de humanidad compartidos tanto por los humildes como por los poderosos, disminuyen eficazmente la estatura y el misterio del pontificado y exponen a los ocupantes del cargo a las formas más bajas del escarnio" (279).

Al declararse el concurso vacante porque todas las justificaciones son muy aceptables, la presidenta de la Cofradía de Santa Águeda le envía al Santo Padre los 200 pesos del premio que no se entregó a ningún concursante, "para que le introdujera mejoras a su inodoro". La respuesta del Santo Papa fue la de un efusivo agradecimiento por "el desprendido gesto de mandarle los 200 pesos para aquella piadosa obra". Enseguida excomulga a perpetuidad a las damas de la Cofradía "por haber intentado penetrar temerariamente en los insondables misterios de la liturgia"; el Papa remata la carta "arrancando violentamente del santoral a Santa Águeda" (319).

Los miembros del Concejo Municipal de Cojontepeque no hallaron relación alguna entre el cuento y el problema de la represa. Entonces don Macario logra ponerlos de acuerdo respecto de la represa haciéndoles ver que la multiplicidad de pareceres "siempre desemboca en un remolino cataclísmico", como ocurrió con las damas del concurso (319-20).

En "El receptáculo ambulante" se puede observar que el inodoro del Santo Papa sirve de agente catalítico para crear un ambiente carnavalesco en el que los concursantes originan un variado abanico de fantasías, algunas escatológicas, otras irreverentes. Además, la humanización del Papa por la presencia del receptáculo ambulante delata su necesidad de satisfacer los bajos menesteres como todo hijo de vecino. Hay que agregar a eso la aceptación efusiva de los 200 pesos, lo cual apunta al pecado de la codicia y apego a los bienes materiales de los representantes de la Iglesia, hasta de los procedentes de la Santa. Además, al acarrear consigo el excusado dondequiera que él vaya, crea un distanciamiento humorístico entre él como pastor cristiano y los feligreses.

En el cuento titulado "Es cuestión de acostumbrarse" (1994b) se continúa la estructura narrativa del cuento-dentro-del-cuento y la sátira carnavalesca de las realidades hispánicas; en este caso, la crítica contra la ignorancia como rémora del progreso: el alcalde de Cojontepeque anuncia un evento que se proclama en forma pomposa "con pregonero, corneta, bombo y platillos" (665) para reunir al pueblo. Ante los atónitos ojos de los aldeanos, les descubre un artefacto que "parecía ser una máquina infernal engendrada en los talleres del Ángel Caído. Incluso los más pesimistas creyeron reconocer en dicho apocalíptico instrumento al mismísimo Lucifer, cosificado, anunciándoles en esa forma peregrina y burlona la inminencia del Juicio Final” (666).

El endemoniado aparato resultó ser nada menos que un moderno inodoro que iba a reemplazar el pozo maloliente, el cual era en el pueblo "un criadero de moscardones, cucarachas y ratas, amén de tarántulas, alacranes y murciélagos" (668). El alcalde les anuncia que será instalado en su propia casa con una cloaca por la que "navegarán alegremente las inmundicias" en lugar de quedar estancadas en el hoyo del retrete como venía ocurriendo. Ante el gran revuelo que se arma en la concurrencia, don Macario, "la voz de la cordura", como de costumbre aplaca los ánimos diciéndoles que "sólo es cosa de acostumbrarse" (669) y enseguida les endilga el ejemplo que se titula "Historia del rey invisible":

Carlos II de Inglaterra era invisible porque se pasaba la vida refocilándose con las damas de la corte y engendrando "vástagos ilegítimos", lo que desprestigiaba a la Corona. El rey deseaba resolver este problema, pero sin dejar de gozar de sus placeres libidinosos. Con 
ese objeto llamó a su médico y le pidió que buscara una solución en el término de una semana y si no la encontraba, perdería la cabeza. En tan gran aprieto, el médico recordó lo versátiles que son las tripas de gato y, poniendo manos a la obra, fabricó una "asquerosa membrana para envainar [el] tubérculo reproductor [del rey] al refocilarse con su amante Lucy Walters, quien, dicho sea de paso, ni por pienso se enteró de que le acababan de meter gato por liebre" (672). Aunque al principio al rey le disgustaba "envainar su protuberancia" en aquella repulsiva membrana, se llegó a acostumbrar "al grado de que ya nunca más pudo entregarse a los placeres de Venus sin recurrir a la famosa membranita". Satisfecho del resultado, le perdonó la vida al médico, "lo elevó a la categoría de Caballero del Rey [...y] además, por decreto real, se le otorgó el nombre de "condón", en honor a su inventor, a la prodigiosa tripa que le había salvado la vida" (672). A partir de entonces todos los cortesanos "se pusieron frenéticamente a ensayar el mismo experimento" (672).

Los habitantes de Cojontepeque no entienden "con exactitud milimétrica" el sentido del relato de don Macario; sin embargo, intuyen que "el progreso invariablemente encuentra al principio enormes obstáculos en su camino, pero que al final siempre sale triunfador", por lo que aceptan el innovador inodoro (673). Además, la esposa del alcalde decide que en el "próximo panfleto turístico de Cojontepeque [...] se incluya el retrato de este glorioso inodoro..." Y promete lo siguiente: "a todo aquel que se aventure a venir a nuestro pueblo le permitiré la entrada en mi casa, por una módica suma de dinero, para que pueda admirar este aparato que tanta conmoción ha provocado entre nosotros" (673-4).

De los cuentos analizados en relación con la escatología y la degradación, éste es el más trivial. No obstante, el eje semántico del texto apunta carnavalescamente al marcado atraso de muchas de las aldeas hispanas representadas por Cojontepeque. También denota la ignorancia y la superstición de los campesinos de algunas regiones del continente.

Otros aspectos de la desacralización e irreverencia en los cuentos de Kattán han sido tratados por Robert A. Parsons en su ensayo sobre el anticlericalismo.

\section{Conclusión}

En conclusión, los textos de Kattán, en lugar de seguir las complicadas técnicas narrativas utilizadas por los escritores actuales, se ciñen a las simples formas populares de los ejemplos medievales y de la estructura del cuento-dentro-del-cuento; esto remite a la intertextualidad intencional de carácter irónico-satírico.

Son cuentos que siguen la línea del realismo grotesco tal como lo definió Bakhtin: en ellos, el lenguaje se libera de convencionalismos y normas establecidas para dar festivamente una visión totalizadora del mundo. Además, el acercamiento cómico irónico-satírico a las deficientes realidades socio-políticas y religiosas junto con la intertextualidad que se presta a ridiculizar costumbres, ideologías, irregularidades, etc., y la escatología dan a esos cuentos un sello carnavalesco.

Asimismo, se observa a lo largo de la narrativa kattaniana una marcada inconformidad con las realidades de El Salvador y de Hispanoamérica. La exageración que los caracteriza, junto con lo que Parsons llama la moderación que subrayan la visión del mundo al revés, festivamente se convierten en armas de ataque contra las irregularidades y los abusos de los poderes políticos y religiosos. 
En general, la obra de Kattán cumple también con la ambivalencia a la cual se asocia el proceso de transformación buscado. Por tanto, se trata de textos que no aceptan ni dogmas, ni autoritarismo, ni una seriedad unívoca y que "se oponen a lo terminado y pulido, a toda pomposidad, a cualquier solución prefabricada en la esfera del pensamiento", como puntualizó Bakhtin al referirse a la imagen rabelaisiana (3). Por lo mismo, para apreciarlos se requiere renunciar a las muchas demandas de los convencionalismos literarios. También hay que verlos a la luz de una larga tradición literaria de protesta, desde Fray Bartolomé de las Casas hasta nuestros días. Sustentan esa protesta las deplorables, injustas y absurdas realidades imperantes en nuestro continente desde la época colonial. A diferencia de esa tradición, el autor subvierte el tono polémico de denuncia, trasgrede los límites del género y efectúa un festivo ataque carnavalesco en el que el mundo es visto al revés.

En suma, las formas carnavalesco-grotescas kattanianas cumplen con la función que Bakhtin señaló en otros autores, la cual consiste en "consagrar la libertad inventiva; permitir la combinación de una variedad de diferentes elementos y un acercamiento a ellos; liberarse del punto de vista predominante en el mundo, de convencionalismos y universalidades aceptadas" (34). Luis Leal (2) apunta que hay en esos cuentos "gran variedad temática y formal, elementos que imparten al contenido — que nada tiene de costumbrismo - una sorprendente nota estética"16.

\section{Notas}

1. Todas las citas tomadas del texto proceden de esta edición. Por lo tanto, sólo se pondrán las páginas entre paréntesis.

2. Originalmente, el manuscrito se titulaba Reminiscencias nostálgicas. Hago esta aclaración porque en algunos estudios relacionados con los cuentos de este libro se menciona dicho título. Este es revelador de una reprimida nostalgia del autor por Quezaltepeque, su terruño salvadoreño que abandonó hace muchos años. Tal aserto lo sustenta la presencia del primer cuento titulado "De cómo el zopilote llegó a ser el redentor de las aves", en el cual predomina el tema de la añoranza de la tierra natal: conociendo la ascendencia palestina de Kattán, el lector se ve tentado a preguntarse cuánto hay del autor mismo en Nabil, hijo de Selim Larach.

3. En Estampas pueblerinas, don Alejo aparece en los siguientes cuentos: "El loco" (33-8), "El resucitado" (41-6), "El cuento lacrimógeno de don Filiberto" (87-92), "El cuento oriental de don Abdalah (95-101) y "El cuento occidental de don Alejo" (105-11).

4. En otros textos del autor, algunos de esos personajes son presentados así: “don Macario Cárcamo, el célebre cronista oficial de Cojontepeque y de las aldeas circunvecinas"; "la sapientísima adivina ña Tomasa Barillas"; "el ex-cura excomulgado don Serapio Topete", quien, según el pueblo, padece de "gula sexual", pero está dotado de un "profundo sentido común, de una comprensión de los males ajenos sin par y siempre dispuesto a ayudar a los que solicitan sus servicios"; "don Indalecio Barrientos, el celebrado brujo del pueblo, sapientísimo solucionador de entuertos".

5. Otras instancias de Estampas pueblerinas que sustentan la tendencia hiperbólica, son: "después de veinte años, Lázaro regresa al pueblo disfrazado y le toca en suerte ver a Ramona, el gran amor de su vida, por la que estuvo a punto de convertirse en un celoso asesino: ahora "le faltaban varios dientes, tenía los ojos hundidos y el pelo cochambroso, y las piernas - que tanta importancia me habían dicho que tenían en las cosas del amor- eran un enmarañado mapa fluvial en bajo relieve construido a base 
de zigzagueantes varices saltonas" (45); "los viscosos tentáculos del Tiempo" habían dejado "convertida a Ramona en un verdadero guiñapo humano" (46).

6. Para un estudio completo de los animales, ver Horacio Peña. 1994. "El bestiario en la narrativa de Jorge Kattán Zablah”. Ars - Revista de la Dirección de Artes (El Salvador) 7: 10-24. Puesto que sería imposible desarrollar en este ensayo todos los elementos que integran el discurso narrativo de Kattán, recomiendo también otro texto de Horacio Peña: "El tiempo en la cuentística de Jorge Kattán Zablah". Círculo 1 (verano de 1996): 12-22.

7. Isolde J. Jordan, “'Los beneficios del mal' y 'los perjuicios del bien': un análisis estilístico de la narrativa de Jorge Kattán Zablah”, Alba de América 30-31 (1998): 287-98. Para más detalles relacionados con la exageración y el lenguaje, recomiendo recurrir a este minucioso estudio.

8. Algunos ejemplos más de Acuarelas son: en el pueblo las autoridades celebran "asambleas cantinescas", y el gringo Mr. Mason se queja de los "pajarracos comecacas"; en otro cuento, el narrador estrecha a Macario "en un tarantulesco abrazo" (48 y 65). En Carnaval: por su paciente espera de una jubilación motivo de sus borracheras, don Elpi merece una "etílica canonización"; es por eso que él "se dirige a velocísimos pasos tortuguescos hacia una segura canonización” $(41,44,47)$ y muchos más que harían interminable este ensayo.

9. Esta sección y la siguiente fueron publicadas con el título de "La intertextualidad como recurso de transgresión y subversión en algunos cuentos de Jorge Kattán Zablah” en Káñina, Revista de Artes y Letras de la Universidad de Costa Rica. Vol. XXI, Número Especial 2 (1997): 63-9.

10. M.Pierrette Malcuzynski. 1988. "New Mythologies: the Case of Mikhail Bakhtin”. Sociocriticism - How to Read Bakhtin. 8: 26. A partir de ahora sólo se mencionará el título de la revista al mencionar otros ensayos importantes relativos a Bakhtin contenidos en dicho ejemplar.

11. Bibliographic Entries: B645, B1118. Extraído de Microsoft Encarta (1994) y America Online (julio 1995).

12. También en Alba de América 30-31 (1998): 555. En este ensayo utilizo la primera versión.

13. Según las noticias de la TV de enero del año 2006, los exiliados salvadoreños enviaron casi $\$ 3.000 .000 .000$ a los familiares que se han quedado en el país.

14. "Los mapaches" fue incluido también en un texto docente para estudiantes del C.B.U., titulado Lecturas guiadas-Textos literarios y no literarios (Montevideo: Editorial A. Monteverde y Cía. S.A., 1995: 7-9).

15. "El brujo" fue publicado también en Foro Literario (Montevideo, Uruguay), 6 (1979).

16. En este ensayo, Leal estudia las diversas formas de ironía en los textos de Kattán: "la ironía verbal como la de situación, la trágica como la cómica", las cuales constituyen el "hilo conductor" que unifica todos los textos de este autor.

\section{Bibliografía}

Bakhtin, Mikhael. 1984. Rabelais and His World. (tr. by Hélène Iswolsky). Bloomington: Indiana University Press. 
Campeny-Queralt, María Rosa. 1996. “El cojontepeque de Jorge Kattán o la recuperación al revés”. Culturadoor. Octubre-noviembre: 12.

Cirlot, Juan Eduardo. 1982. Diccionario de símbolos. Barcelona: Editorial Labor S.A.

Jordan, Isolde J. 1998. “'Los beneficios del mal' y 'los perjuicios del bien’: un análisis estilístico de la narrativa de Jorge Kattán Zablah”. Alba de América (30-31): 287-98.

Kattán Zablah, Jorge. 1981. Estampas pueblerinas. San José, Costa Rica: Editorial Texto Ltd. 1983. Acuarelas socarronas. Barcelona: Ediciones Ronda.

1993. "El peligroso juego de la multiplicidad de pareceres". Confluencia. 8-9: 315-21. 1994a. "La frágil naturaleza humana". Confluencia. 1: 194

1994b. "Es cuestión de acostumbrarse". Alba de América. 22-23: 665-74.

1995. “De la magnanimidad de Dios, ¡líbranos, Luzbel! Culturadoor. 20: 15.

1996. "La infalibilidad de la sibila". Culturadoor. 21: 3.

1998. Por el carnaval de la vida. San José, Costa Rica: Editorial Perro Azul.

Leal, Luis. 1996. "Espejo cómico, absurdo y trágico de la comedia humana en Centro América-Jorge Kattán Zablah: cuento pequeño, grande ironía”. Culturadoor. 25.

Malcuzynski, M. Pierrette. 1988. "New Mythologies: the Case of Mikhail Bakhtin". Sociocriticism - How to Read Bakhtin. 8.

Parsons, Robert. 1998. "Sátira anticlerical en algunos cuentos de Jorge Kattán Zablah”. Alba de América. 30-31: 269-85.

Ricci, Julio. 1987. Los mareados. Montevideo: Monte Sexto.

Rojas, Francisco. 1955. El diosero. México: Fondo de Cultura Económica.

Siègle, Robert. "Bakhtin and sociocriticism". Sociocriticism. 8: 72.

Zavala, Iris. 1988. "Bahktin Versus the Postmodern”. Sociocriticism: 59-60.

Zlotchew, Clark M. 1990. "Humorismo satírico en la narrativa de Jorge Kattán Zablah". Alba de América. 14-15: 149-56. 